\title{
KONFLIK DAN EKSISTENSI LEMBAGA ADAT LOKAL
}

\author{
Rahmat Panji \\ Jurusan Ilmu Politik, Fisip, Universitas Andalas \\ Email: Ikoawakpanji@gmail.com
}

\begin{abstract}
Abstrak
Penelitian ini melihat konflik dalam suatu kepengurusan yang terorganisir dan terstrukur. Objek dalam penelitian ini adalah Kerapatan Adat Nagari (KAN) Lubuk Kilangan, KAN merupakan lembaga adat yang mengurusi persoalan sako, puasko dan anak kamanakan. Fungsi KAN yang begitu sentral di Lubuk Kilangan terkait dengan tanah ulayat (bukit karang putih) yang digunakan oleh PT Semen Padang malah menjadikan perpecahan pada niniak mamak Lubuk Kilangan. Konflik ini berawal dari perebutan wewenang dalam struktur kepengurusan KAN Lubuk Kilangan. Penelitian ini bertujuan untuk melihat bentuk serta penyebab terjadinya konflik kepengurusan KAN Lubuk Kilangan. Penelitian ini menggunakan metode kualitatif deskriptif dengan tipe studi kasus dan pengumpulan data dengan teknik wawancara dan dokumentasi. Penelitian ini menemukan bahwa konflik kepengurusan KAN Lubuk Kilangan merupakan bentuk dari perebutan kewenangan antar niniak mamak untuk mendapatkan sumber-sumber yang dimiliki dalam KAN Lubuk Kilangan. Perebutan wewenang dalam kepengurusan KAN Lubuk Kilangan dilakukan dengan membentuk kelompok yang terorganisir (KAN Baru) untuk menandingi keberadaan KAN Lubuk Kilangan periode 2017-2022. Proses pembentukan kelompok yang terorganisir merupakan bentuk dari kelompok bertentangan yang dijalankan secara baik sehingga mendapatkan legitimasi yang kuat dari LKAAM Kota Padang, legitimasi ini membuat semakin jelasnya perebutan wewenang yang dilakukan dalam kepengurusan KAN Lubuk Kilangan.
\end{abstract}

Kata Kunci : Konflik, Kerapatan Adat Nagari, Niniak Mamak

\begin{abstract}
This research was conducted to see the conflict in an organized and structured management. The object of this research is the Nagari Indigenous Density (KAN) Lubuk Kilangan, KAN is a traditional institution that deals with the issue of sako, satisfiedko and children of kamanakan. The function of KAN, which is so central in Lubuk Kilangan, is related to the ulayat land (white coral hill) used by PT Semen Padang, instead creating a split in the mamak Lubuk Kilangan. the conflict that occurred in the management of KAN Lubuk Kilangan started from the struggle for authority in the management structure of KAN Lubuk Kilangan. So that researchers aim to see the forms and causes of conflict in the management of KAN Lubuk Kilangan so that they can be anticipated in the future, so that these traditional institutions always remain escalating. In this study, researchers used a descriptive qualitative method with the type of case study, this study conducted data collection with interview and documentation techniques. The data that the researcher obtained was also tested for validity through triangulation of data sources. The results of this study prove that the conflict management of KAN Lubuk Kilangan is a form of the struggle for authority between mamak Lubuk Kilangan niniak to obtain resources owned in KAN Lubuk Kilangan. The struggle for authority that occurred in the management of KAN Lubuk Kilangan was carried out by forming an organized group (KAN Baru) to counter the existence of KAN Lubuk Kilangan for the period of 2017-2022. The process of forming organized groups is a form of conflicting groups that are carried out well so as to get strong legitimacy from LKAAM Padang City, this legitimacy makes clearer the struggle for authority carried out in the management of KAN Lubuk Kilangan.
\end{abstract}

Keyword ; Conflict, Kerapatan Adat Nagari, Niniak Mamak 


\section{PENDAHULUAN}

Adat bagi masyarakat Minangkabau adalah peraturan hidup. Secara tidak langsung adat bersifat mengikat dalam menjalankan kehidupan sehari-hari untuk tunduk dan mematuhinya. Upaya ini digunakan agar adat tidak menjadi "semboyan bibir" yang tak punya arti dan fungsi apa-apa. Demi tercapai keinginan tersebut muncullah Kerapatan Adat Nagari (KAN) untuk mengurus dan mengelola hal-hal yang berkaitan dengan adat. Peran KAN yang dominan dalam suatu nagari, sangat penting dalam menjalankan dan menyelesaikan perkara adat untuk kepentingan masyarakat nantinya. Peran sentral KAN yang lekat dengan permasalahan adat bisa menimbulkan konflik baik dalam kepengurusan KAN tersebut dan juga antara KAN dengan masyarakat nagari pada saat sekarang.

Lembaga pertama yang dihasilkan dan diberi otoritas oleh komunitas orang Minangkabau adalah mamak, kemudian berkembang ke atas kepada penghulu kemudian berpucuk kepada kerapatan adat, yaitu Kerapatan adat Nagari (KAN) ${ }^{1}$. KAN dalam suatu nagari memiliki tugas mengurus dan mengelola hal-hal yang berkaitan dengan adat sehubungan sako dan pusako, menyelesaikan perkara adat dan adat istiadat, mengusahakan perdamaian dan memberikan kekuatan hukum terhadap anggota masyarakat yang bersengketa serta memberikan kekuatan hukum terhadap sesuatu hal dan pembuktian lainnya menurut sepanjang adat, menginventarisasi, menjaga, memelihara dan mengurus serta memanfaatkan kekayaan nagari untuk meningkatkan kesejahteraan masyarakat nagari dan mewakili nagari serta bertindak langsung atas nama dan untuk nagari dalam segala perbuatan hukum di dalam dan di luar pengadilan untuk kepentingan dan atau hal-hal yang menyangkut dengan hak dan harta kekayaan milik nagari. ${ }^{2}$ kerapatan Adat Nagari (KAN) di isi oleh pucuak adat, datuak- datuak kaampek suku, penghulu- penghulu andiko, urang ampek jinih dan manti nagari ${ }^{3}$. Keberadaan KAN secara garis besar memang berakar di dalam suatu nagari, berbeda hal dengan kota KAN diurut dari nagari yang pernah ada di Kota Padang. Kota Padang dahulunya memiliki 10 nagari maka ada 10 KAN di Kota Padang ${ }^{4}$. Salah satu KAN yang sangat aktif di Kota Padang adalah KAN Lubuk Kilangan, KAN Lubuk Kilangan diisi oleh urang nan ampek jinih (penghulu, malin, manti dan dubalang) dari masing-masing suku. KAN Lubuk Kilangan merupakan KAN yang masih aktif di Kota Padang hal ini dikarenakan tanah ulayat yang ada di Lubuk Kilangan digunakan oleh PT Semen Padang untuk menjadi bahan baku pabrik.

Masyarakat Lubuk Kilangan merasakan dampak dari keberadaan KAN di Kecamatan ini. Pada sebuah nagari seluruh tanah yang berada di nagari tersebut disebut dengan tanah kaum bukan tanah pemerintah. Hal ini menjadi pembeda antara nagari dengan desa yang secara garis besar nagari lahir secara geneologis dan historis. Sehingga kehadiran KAN Lubuk Kilangan

\footnotetext{
${ }^{1}$ Mohammad Hasbi, Mochtar Naim,(1990), Nagari Desa dan Pembangunan Pedesaandi Sumatera Barat, Yayasan Genta Budaya ,Payakumbuh, 1990. hlm. 5.

${ }^{2}$ Amir M.S, Adat Minangkabau "Pola dan Tujuan Hidup Orang Minang”, Citra Harta Prima,Jakarta, 2003. Hlm. 57.

${ }^{3}$ Ibid., hlm. 128.
} 
sangat diperlukan oleh masyarakat Lubuk Kilangan. KAN Kecamatan Lubuk Kilangan sebagai lembaga adat memiliki kewajiban menjaga tanah ulayat yang digunakan PT Semen Padang tersebut. Oleh karena itu perjalanan tanah ulayat yang digunakan oleh PT Semen Padang tersebut memiliki andil besar dalam perkembangan dan pembangunan Kecamatan Lubuk Kilangan. Tanah ulayat yang sangat besar, digunakan oleh PT Semen Padang tersebut, sudah dipercayakan oleh setiap suku kepada niniak mamaknya yang berada di Kerapatan Adat Nagari. Berdasarkan fungsinya KAN sebagai lembaga adat memiliki kewenangan tradisional, sebagai lembaga yang sudah turun-temurun di Minangkabau. Kewenangan yang dimiliki oleh KAN dapat menghadirkan sebuah ketimpangan dalam kepengurusan KAN Lubuk Kilangan. Konflik dalam kepengurusan KAN merupakan bentuk dari perebutan kewenangan tradisional. Menyangkut pada fungsi dan tugas yang telah dilaksanakan oleh KAN Lubuk Kilangan semasa kepengurusan.

Kewenangan dalam suatu masyarakat sangat lekat dengan penguasa dan yang dikuasai. Kewenangan dalam hal kekuasaan memiliki peran besar karena dapat mempengaruhi suatu keputusan ${ }^{5}$. Pada hal ini kewenangan merupakan hak moral untuk membuat dan melaksanakan keputusan. Max Webber membagi kewenangan dengan tiga tipe yaitu kewenangan tradisional, kewenangan karismatik dan kewenangan legal rasional. Namun, pada penelitian ini peneliti lebih memfokuskan pada kewenangan tradisional dalam kasus dualisme kepengurusan Kerapatan Adat Nagari (KAN) Lubuk Kilangan. Kewenangan tradisional yaitu kewenangan yang didasarkan atas tradisi, kebiasaan, kekudusan dan kekuatan zaman dahulu.

Perebutan kewenangan yang terjadi dalam kepengurusan KAN Lubuk Kilangan, sehingga terjadilah konflik. Konflik dapat terjadi karena adanya keinginan manusia untuk menguasai sumber-sumber dan posisi yang langka. Hal seperti ini biasanya sering berkaitan dengan kekuasaan dan kewenangan. Kekuasaan dan kewenangan dalam suatu masyarakat bisa dianggap hal yang langka karena di dalam suatu masyarakat hanya sedikit yang akan menjadi pemimpin dan memiliki kewenangan untuk mengatur kelompok masyarakat. Sama halnya dengan sumbersumber, posisi atau kedudukan, jabatan adalah hal yang langka dalam masyarakat. Kedudukan sebagai penguasa negara umpamanya, merupakan bahan rebutan di antara anggota-anggota masyarakat yang menghasilkan konflik Keberadaan KAN yang pada dasarnya adalah menjaga dan mengawasi permasalahan ada pada masyarakat Minangkabau. Peran sentral KAN inilah yang membuat lembaga tersebut masih bertahan pada masa sekarang. Dominasi KAN yang sudah mulai pudar, banyak menimbulkan permasalahan pada lembaga tersebut. Kasus konflik kepengurusan KAN Lubuk Kilangan merupakan bentuk dari sudah berkurangnya legitimasi KAN yang sudah diakui semenjak dahulu oleh masyarakat Lubuk Kilangan. Tentunya dengan unsur dan latar belakang tertentu konflik kepengurusan ini dapat terjadi. Maka dari itu penelitian ini akan menjawab pertanyaan penelitian yaitu: Bagaimana terjadinya konflik kepengurusan KAN Lubuk Kilangan Periode 2017-2022.

Tujuan dari penelitian ini antara lain untuk menjelaskan bentuk konflik Kepengurusan KAN Lubuk Kilangan dan menjelaskan penyebab terjadinya konflik kepengurusan KAN Lubuk Kilangan periode 2017-2022. Secara keseluruhan, ada yang menjadi pilihan peneliti yang

${ }^{5}$ Ibid., hlm 6. 
dianggap cukup relevan untuk diajukan sebagai rujukan bagi penulisan penelitian ini adapun penelitian terdahulu. Pertama, karya ilmiah berupa jurnal yang diteliti oleh Nuraini Budi Astuti, Lala M. Klopaking dan Nurmala K. Pandjaitan. Dalam Jurnal transdisiplin Sosiologi, Komunikasi dan Ekologi Manusia yang mana penelitian tersebut berjudul "Dilema dalam Transformasi Desa ke Nagari Studi Kasus di Kenagarian IV Koto Palembayan, Provinsi Sumatera barat”. Jurnal ini meneliti tentang bagaimana dilemma transformasi kelembagaan desa ke nagari, kelmbagaan yang menjadi prioritas disini adalah lembaga adat yang pada saat ini memiliki posisi yang tumpang tindih dalam pemerintahan nagari. Setelah diberlakukan UU No 5 tahun 1979 penyerataan struktur pemerintahan terendah dengan desa menjadi satu polemik yang harus diselesaikan dengan memecah nagari menjadi desa.

Kedua, karya ilmiah berupa jurnal yang diteliti oleh Riski Fazila, Maimun, dalam Jurnal Ilmiah Mahasiswa FISIP Unsyiah yang mana penelitian tersebut berjudul "Dualisme Kepengurusan Pusat Partai Persatuan pembangunan Menjelang Pilkada Serentak 2017 Kajian Terhadap Dewan Pimpinan Partai Persatuan Pembangunan Aceh)"6. Penelitian ini mengambarkan bagaimana peneyebab terjadinya dualisme kepengurusan pusat Partai Persatuan Pembangunan (PPP) yang berawal dari keputusan koalisi yang diambil oleh ketua partai yaitu Surya Dharma Ali membuat kondisi partai menjadi tidak stabil. Keputusan sepihak yang diambil oleh ketua partai tidak mengakomodir seluruh elemen yang ada didalam partai. Keadaan ini memunculkan dualisme dalam kepengurusan Partai Persatuan Pembangunan.

Ketiga, penelitian yang dilakukan oleh Yayan Hidayat, Iwan I. Febrianto dan Mahalli, dalam jurnal ilmiah Indonesian Political Science Review yang mana penelitian tersebut berjudul "Transformasi dan Dualisme kelembagaan dalam Pemerintahan Adat Minang: Studi Terhadap Nagari Pariangan Sumatera Barat"7. Penelitian ini menggambarkan dampak dari dualisme kelembagaan di Nagari Pariangan yang disebabkan oleh kontestasi kontrol sosial antara Negara dan pemerintah daerah melalui UU Nomor 5 Tahun 1979 dan Perda Sumatera Barat Nomor $2 / 2007$.

Konflik adalah perbedaan kepentingan (Ipreceived divergence of interest), atau suatu kepercayaan bahwa aspirasi pihak-pihak yang berkonflik tidak dapat dicapai secara simultan $^{8}$. Oleh karena itu banyak pihak menganggap bahwa konflik adalah sesuatu yang merusak. Karl Marx juga ikut menyumbangkan pemikiran menyangkut konflik dalam materialisme dialektika Marx melihat fakta bahwa konflik mendorong timbulnya konflik lebih lanjut, bahwa perubahan tidak dapat dihindari dan bahwa paling tidak menurut pendapatnya, perubahan ini hampir selalu mengarah pada mutu kondisi peningkatan masyarakat ${ }^{9}$. Menurut Dean G. Pruitt dan Jeffrey Z. Rubin konflik bisa terjadi karena salah satu pihak memiliki aspirasi tinggi atau karena alternative yang bersifat integrative (kesepahaman) sulit didapatkan ${ }^{10}$. Sehingga ketika membahas konflik

\footnotetext{
${ }^{6}$ Riski Fazila, Maimun (2017), “Dualisme Kepengurusan Pusat Partai Persatuan Pembangunan MenjelangPilkada Serentak 2017 (Satuan Kajian Terhadap Dewan Pimpinan Partai Persatuan Pembangunan Aceh)”, Jurnal Ilmiah FISIP Unsyiah Volume 2,(2) : Hlm 481-501.

7 Yayah Hidayat, Iwan I. febrianto dan Mahalli, "Transformasi dan Dualisme Kelembagaan dalam Pemerintahan Adat Minang: Studi Terhadap Nagari Pariangan sumatera Barat", Politik Indonesia Political Science Review, Volume 2,(2) 2017 : 227-245.

${ }^{8}$ Dean G. Prit dan Jeffrey Z. Rubin, Teori Konflik, Pustaka Pelajar, 2011, hlm, 10.

${ }^{9}$ Karl Marx dirujuk dari Dean G. Prit dan Jeffrey Z. Rubin, Teori Konflik, Pustaka Pelajar, 2011, hlm, 10.

${ }^{10}$ Ibid., hlm, 27
} 
seharusnya lebih fokus pada perbedaan persepsi nilai atau kepentingan ${ }^{11}$. Ralf Dahrendorf juga ikut menyumbangkan konsep dalam konflik, melihat kekurangan dari teori struktural-fungsional. Menurutnya dalam memahami masyarakat haruslah melihat dialektika stabilitas dan perubahan, integritas dan pertentangan, fungsi dan kekuatan motif, konsensus dan penggunaan kekuasaan ${ }^{12}$. berdasarkan asumsi tentang sifat memaksa dari sturuktur sosial, bagaimana hubungan-hubungan kekuasaan menjadi penghasil bentrokan-bentrokan kepentingan yang mana berdasarkan kondisi tertentu menyebabkan terbentuknya kelompok-kelompok yang bertentangan baik dalam organisasi sosial yang terbatas maupun dalam masyarakat keseluruhan ${ }^{13}$. Kelompok yang bertentangan dalam konsep Dahrendorf tidak semata hadir begitu saja namun melalui sebab akibat yang melatar belakanginnya. Dahrendorf menambahkan (1) pembagian wewenang dalam perserikatan adalah penyebab utama terbentuknya kelompok yang bertentangan, dan (2) dikotomi dalam setiap perserikatan adalah penyebab terbentuknya dua dan hanya dua, kelompok yang bertentangan ${ }^{14}$.

Berdasarkan penjelasan dan pengertian konflik diatas untuk dapat memahami dan menelaah konflik lebih jelas terkait konflik kepengurusan KAN Lubuk Kilangan peneliti menggunakan penyebab konflik sebagai konsep penenunjang penelitian ini. Pada konsep konflik diatas Dahrendorf berpandangan bahwa akibat terjadinya konflik dalam suatu organisasi adalah kekuasaan dan pembagian wewenang sehingga menyebabkan terbentuknya kelompok yang bertentangan. Pengertian kelompok yang seharusnya adalah sekumpulan orang yang berhubungan atau berkomunikasi secara teratur dan mempunyai sebuah struktur yang dapat dikenal ${ }^{15}$. Sehingga peneliti beramsumsi bahwa konflik kepengurusan KAN berasal dari konflik kelompok yang bertentangan.

Perbedaan pembagian kekusaan dan wewenang bisa masuk dalam kategori penyebab konflik kelompok yang bertentangan. Pernyataan ini didukung dalam konsep Dahrendorf perbedaan pembagian kekuasaan dan wewenang senantiasa menjadi faktor yang menentukan jenis pertentangan sosial ${ }^{16}$.

Ralf Dahrendorf juga menambahkan ada tiga kondisi yang mendukung terbentuknya kelompok yang bertentangan sehingga sering memunculkan konflik diantaranya:

1. Komunikasi terus-menerus antara orang-orang senasib;

2. Ada seseorang pemimpin yang membantu mengartikulasikan ideologi, mengorganisasikan kelompok dan memformulasikan rencana untuk melakukan tindakan kelompok;

3. Legitimasi kelompok dimata komunitas yang lebih luas atau setidaknya tidak ada tekanan komunitas yang efektif terhadap kelompok ${ }^{17}$.

Permasalahan konflik yang terjadi dalam kepungurusan KAN Lubuk Kilangan bisa terjadi karena faktor kekuasaan yang erat pada lembaga KAN. Peran sentral yang dimiliki oleh lembaga KAN bisa menimbulkan penyebab konflik seperti yang dijelaskan ketika salah satu pihak merasa lebih pantas untuk memegang tanggung jawab yang dimiliki oleh KAN yang sudah

\footnotetext{
${ }^{11}$ Ibid., hlm, 27

${ }^{12}$ Ralf dahrendorf, Konflik dan Konflik Dalam Masyarakat Industri, CV Rajawali, Jakarta, 1986, hlm,199.

${ }^{13}$ Ibid., hlm. 201.

${ }^{14}$ Ibid., hlm. 211.

${ }^{15}$ Dahrendorf, Op.cit, hlm. 221.

${ }^{16}$ Ibid., hlm, 201.

${ }^{17}$ Ralf Dahrendorf dirujuk dari Dean G. Prit dan Jeffrey Z. Rubin, Teori Konflik, Pustaka Pelajar, 2011.
} 
ada tersebut. Sehingga peneliti melihat kemungkinan ada kecemburuan yang terjadi antar pengurus KAN Lubuk Kilangan

Dahrendorf juga menambahkan penyebab terjadinya kelompok yang bertentangan tersebut. Pada bukunya konsep kelompok yang bertentangan dapat hadir melalalui kelompok semu dan kelompok kepentingan. Kelompok semu merupakan unit-unit yang dibangun untuk menrangkan masalah sedangkan kelompok kepentingan adalah agen yang sesungguhnya dari pertentangan kelompok ${ }^{18}$. Kelompok kepentingan nantilah yang akan menjalin komunikasi antar anggotanya melalui penunjukan wakil-wakil dari kelompok tersebut.

Dean G. Pruitt dan Jeffrey Z. Rubin juga menjalaskan fenomena seperti itu biasanya disebut sebagai individious comparison (pembandingan yang menyakit hati) ${ }^{19}$. Hal itu seakan menjadi stimulus dalam peningkatan aspirasi untuk alasan yang dianggap realistis, (karena rasanya masuk akal bila orang yang menjadi pembandingnya dapat melakukan sesuatu maka ia seharusnya dapat juga melakukan hal yang sama. Oleh karena itu akan terbentuk kelompok pejuang (struggle group), kelompok pejuang bisa terjadi salah satu pihak merasa kepentingannya terpisah dengan kelompok lain. Kelompok pejuang muncul ketika beberapa orang dengan kepentingan laten (tidak disadari) yang sama saling berbincang, maka kepentingan laten tersebut tanpa disadari muncul ke kesadaran setelah merasa yakin dengan kepentingan mereka masingmasing mereka mungkin akan mulai mengembangkan aspirasi baru yang mengarah pada konflik dengan orang lain yang kepentingannya bertentangan dengan aspirasi tersebut ${ }^{20}$.

\section{METODE PENELITIAN}

Dalam tradisi penelitian kualitatif, proses penelitian dan ilmu pengetahuan tidak sesederhana apa yang terjadi dalam penelitian kuantitatif, karena sebelum hasil-hasil penelitian kualitatif memberi sumbangan kepada ilmu pengetahuan, tahapan penelitian kualitatif melampaui berbagai tahapan kritis-ilmiah, yang mana seorang peneliti memulai berpikir secara induktif, yaitu menangkap berbagai fakta atau fenomena-fenomena sosial, melalui pengamatan di lapangan kemudian menganalisis nya dan kemudian berupaya melakukan teorisasi berdasarkan apa yang diamati itu.

Jenis penelitian menggunakan metode studi kasus dengan tipe penelitian yang digunakan adalah deskriptif, tipe penelitian deskriptif yaitu data yang terkumpul berbentuk kata-kata, gambar bukan angka-angka. Kalaupun ada angka hanya sebagai penunjang. Data pada penelitian studi kasus bisa diperoleh dari transkrip interview, catatan lapangan, foto dokumen pribadi, pengamatan langsung dan lain-lain. Metode studi kasus telah dijelaskan oleh Robert K.Yin di dalam bukunya bahwasannya studi kasus digunakan sebagai suatu penjelasan komprehensif yang berkaitan dengan berbagai aspek seseorang, suatu kelompok, suatu organisasi, suatu program, atau suatu situasi kemasyarakatan yang diteliti, diupayakan dan ditelaah sedalam mungkin ${ }^{21}$. Maka dalam penelitian ini, peneliti akan menggunakan metode deskriptif untuk menjelaskan

\footnotetext{
${ }^{18}$ Dahrendorf, Op.cit., hlm. 222.

${ }^{19}$ Ibid., hlm, 33.

${ }^{20}$ Ibid., hlm, 34.

${ }^{21}$ Robert K, Yin, “Studi Kasus (Desain dan Metode)”, PT Raja Grafindo Persada, Jakarta, 2003.
} 
Konflik Kepengurusan Kerapatan Adat Nagari (KAN) Lubuk Kilangan.

\section{HASIL DAN PEMBAHASAN}

Tabel 1. Kronologis Konflik

\begin{tabular}{|c|c|c|c|c|}
\hline No & Tanggal & Peristiwa & Aktor & Keterangan \\
\hline 1. & $\begin{array}{ll}26 & \text { Juli } \\
2017 & \end{array}$ & $\begin{array}{l}\text { Musyawarah Pemilihan } \\
\text { Ketua KAN Lubuk } \\
\text { Kilangan }\end{array}$ & $\begin{array}{l}24 \text { niniak mamak } \\
\text { Lubuk Kilangan }\end{array}$ & $\begin{array}{l}\text { Terpilih Basri Dt Rajo } \\
\text { Usali Periode 2017-2022 }\end{array}$ \\
\hline 2. & $\begin{array}{l}5 \text { Agustus } \\
2018\end{array}$ & $\begin{array}{l}\text { Pengumuman } \\
\text { kepengurusan } \\
\text { periode } 2017-2022\end{array}$ & Basri Dt Rajo Usali & $\begin{array}{l}\text { Tepilih } 5 \text { niniak mamak } \\
\text { pada kepengurusan inti }\end{array}$ \\
\hline 3. & $\begin{array}{l}\text { Agustus } \\
2017\end{array}$ & $\begin{array}{l}\text { Ada beberapa niniak } \\
\text { mamam yang tidak suka } \\
\text { dengan nama } \\
\text { kepengurusan baru }\end{array}$ & $\begin{array}{l}\text { Nawirman } \\
\text { Mangguang }\end{array}$ & $\begin{array}{l}\text { Mencoba melemahkan } \\
\text { kepengurusan Bari Dt } \\
\text { Rajo Usali }\end{array}$ \\
\hline 4. & $\begin{array}{l}\text { Agustus } \\
2017\end{array}$ & $\begin{array}{l}\text { Penuntutan pelaporan } \\
\text { LPJ Kepngurusan lam }\end{array}$ & $\begin{array}{ll}\text { Beberapa } & \text { niniak } \\
\text { mamak } & \text { Lubuk } \\
\text { Kilangan } & \end{array}$ & $\begin{array}{l}\text { Meminta keterangan atas } \\
\text { kepengurusan yang lama }\end{array}$ \\
\hline 5. & $\begin{array}{l}\text { 5Februari } \\
2018\end{array}$ & $\begin{array}{l}\text { Surat pernyataan sikap } \\
\text { terhadap kepengurusan } \\
\text { KAN Lubuk Kilangan }\end{array}$ & $\begin{array}{l}13 \text { orang niniak } \\
\text { mamak Lubuk } \\
\text { Kilangan }\end{array}$ & $\begin{array}{l}\text { Mengajukan } 4 \text { tuntutan } \\
\text { terhadap kepengurusan } \\
\text { lama }\end{array}$ \\
\hline 6. & 24 Maret & Musyawarah Nagari & 180 peserta (niniak & Membentuk \\
\hline & 2018 & $\begin{array}{l}\text { Luar Biasa Lubuk } \\
\text { Kilangan }\end{array}$ & $\begin{array}{l}\text { mamak, anak nagari, } \\
\text { dan tokoh masyarakat } \\
\text { Lubuk Kilangan) }\end{array}$ & $\begin{array}{l}\text { kepengurusan KAN baru } \\
\text { dibawah kepemimpinan } \\
\text { Junaidi Usman Dt Rajo } \\
\text { Brahim }\end{array}$ \\
\hline 7. & $\begin{array}{l}23 \quad \text { April } \\
2018\end{array}$ & $\begin{array}{l}\text { LKAAM Kota Padang } \\
\text { menerbitkan Surat } \\
\text { Keputusan No. } \\
\text { 045/LKAAM- } \\
\text { Padang/IV-2018 }\end{array}$ & $\begin{array}{l}\text { Ketua dan sekretaris II } \\
\text { LKAAM Kota Padang }\end{array}$ & $\begin{array}{l}\text { Bentuk legitimasi atas } \\
\text { pengurusan Baru KAN } \\
\text { Lubuk Kilangan }\end{array}$ \\
\hline 8. & $\begin{array}{l}3 \quad \text { Mei } \\
2018\end{array}$ & $\begin{array}{l}\text { Pengukuhan } \\
\text { Kepengurusan Baru } \\
\text { KAN Lubuk Kilangan }\end{array}$ & $\begin{array}{l}\text { LKAAM Kota Padang } \\
\text { dan Kepengurusan } \\
\text { KAN Baru }\end{array}$ & $\begin{array}{l}\text { Kantor KAN Baru } \\
\text { Lubuk Kilangan }\end{array}$ \\
\hline
\end{tabular}

Bentuk Konflik Kepengurusan Kerapatan Adat Nagari (KAN) Lubuk Kilangan Periode 2017-2022

Bentuk konflik secara garis besar bisa kita kategorikan kedalam bentuk fisik dan juga bentuk dan juga bentuk lisan. konflik fisik biasanya melibatkan benda-benda dalam perbedaan pendapat sedangkan konflik lisan yaitu percekcokan antar dua orang. Pada konflik kepengurusan 
KAN Lubuk Kilangan jika kita menggunakan konsep Maswadi Rauf konflik ini tentu masih di tahap konflik lisan, namun konflik lisan ini sudah laten karena sudah berjalan lebih dalam 1 tahun. Peneliti juga menemukan bahwa sudah banyak cara dari berbagai pihak untuk menyelesaikan persoalan konflik ini tapi belum menemukan hasil yang bisa menguntungkan kedua belah pihak sehingga konflik ini masih terus berlangsung.

\section{Terbentuknya Kelompok yang Bertentangan dalam Kepngurusan KAN Lubuk Kilangan Periode 2017-2022}

Dahrendorf menyebutkan ada tiga kondisi yang mendukung kemunculan kelompok yang bertentangan yang sering kali menjadi pendorong terjadinya konflik, yaitu (1) komunikasi terus menerus antara orang senasib (2) adanya seorang pemimpin yang membantu mengartikulasikan ideology, mengorganisasikan kelompok dan memformulasikan rencana untuk melakukan tindakan kelompok (3) legitimasi kelompok dimata komunitas yang lebih luas atau setidaknya ada tekanan komunitas yang efektif terhadap kelompok ${ }^{22}$. Berdasarkan pandangan ini peneliti akan mengidentifikasi terbentuknya kelompok yang bertentangan dalam konflik kepengurusan KAN Lubuk Kilangan. Pertama, komunikasi terus menerus diantara orang orang senasib, hal ini sejalan dengan yang dilakukan oleh Nawirman ketika mengajak Zulbahri dan Junaidi Usman. Pertemuan yang dilakukan oleh Nawirman dengan Zulbahri sudah lebih 3 kali sebelum bertemu dan mengajak Junaidi usman untuk dapat terlibat dalam kelompok yang mereka siapkan ${ }^{23}$. Pertemuan yang dilakukan dengan Junaidi Usman hanya sekali hal namun lama sehingga membuat Junaidi Usman setuju dengan beberapa keresahan yang dikedepankan oleh Nawirman yang diantaranya bahwa sudah banyaknya anak nagari merasakan ketidakadilan atas kepemimpinan KAN lama dalam mengambil keputusan yang selalu menurut anak nagari berpihak pada PT Semen Padang persoalan ini selalu menyangkut tanah ulayat yang digunakan oleh PT Semen Padang ${ }^{24}$. Dalam terbentuknya KAN baru juga melibatkan banyak elemen diantaranya ada 10 niniak mamak dan anak nagari juga tokoh nagari. terlibatnya niniak mamak merupakan peran dari Nawirman, Zulbahri dan Junai Usman dimana mereka bertiga lah yang mencoba membangun komunikasi sehingga muncul kesepakatan 13 niniak mamak menuntut kepengurusan KAN dibawah kepemimpinan Basri Dt Rajo Usali. Pada kalangan anak nagari dan tokoh nagari komunikasi ini dibangun oleh Nawriman menggunakan kegelisahan terkait persoalan tanah ulayat masyarakat yang seringkali berpihak pada PT Semen Padang ${ }^{25}$.

Ruang-ruang komunikasi yang dibangun oleh Nawirman Zulbahri dan Junaidi Usman tersebutlah yang membuat kelompok bertentangan dalam konflik kepengurusan KAN Lubuk Kilangan. terbentuknya kelompok yang bertentangan dalam kepengurusan KAN Lubuk Kilangan memang sangatlah dibilang sangat singkat karena hanya dalam kurun waktu 5 bulan dari

\footnotetext{
${ }^{22}$ Ibid., hlm. 35.

${ }^{23}$ Wawancara Bersama Junaidi Usman Dt Rajo Brahim Sebagai Ketua KAN baru Lubuk Kilangan, Tempat diKantor KAN baru Lubuk Kilangan yang Sekaligus Kediamannya.

${ }^{24}$ Wawancara Bersama Junaidi Usman Dt Rajo Brahim Sebagai Ketua KAN baru Lubuk Kilangan, Tempat diKantor KAN baru Lubuk Kilangan yang Sekaligus Kediamannya.

${ }^{25}$ Wawancara Bersama Junaidi Usman Dt Rajo Brahim Sebagai Ketua KAN baru Lubuk Kilangan, Tempat diKantor KAN baru Lubuk Kilangan yang Sekaligus Kediamannya.
} 
keluarnya nama pengurus oleh pada kepemimpinan Basri Dt Rajo Usali periode 2017-2022 yaitu pada bulan desember hingga bulan mei sudah terbentuk KAN Baru dibawah legitimasi dari LKAAM Kota Padang.

Kedua, adanya seorang pemimpin yang membantu mengartikulasikan ideology, mengorganisasikan kelompok dan memformulasikan rencana untuk melakukan tindakan kelompok. Jika peneliti merunut berdasarkan Kronologis diatas Nawirman merupakan seorang pemimpin dari terbentuknya kelompok yang bertentangan dalam konflik kepengurusan Lubuk Kilangan. hal ini dapat dibenarkan dengan keinginan Nawirman ketika bertemu dengan Junaidi Usman yang ingin sekali mengembalikan hak dari anak kamanakan Lubuk Kilangan dalam persoalan tanah ulayat yang merupakan milik mereka.

Setelah mengedepankan keinginan yang menjadi landasan dari keinginan tersebut akhirnya beliau mendapat sokongan dari Junaidi Usman guna memperkuat keyakinan beliau. Sedangkan pada perjalanannya ada 3 niniak mamak yang memiliki peran penting dalam mengartikulasikan tuntutan yang ternyata juga dirasakan oleh 10 niniak mamak lainnya. Pada saat inilah fungsi 3 niniak mamak ini sangat sentral sekali dalam membangun kelompok yang bertentangan. Peran mereka yang membangun kelompok semu dapat kita temukan dengan melihat adanya tuntutan yang disosialisasikan pada niniak mamak lainnya.

Peran dari 3 niniak mamak inilah juga yang membuat terealisasikannya Musnalub Lubuk Kilangan untuk dapat mencapai tujuan kelompok mereka yaitu membubarkan kepengurusan Basri Dt Rajo usali. Melalui komunikasi antara orang senasib mereka memiliki tujuan yang jelas dan juga tuntutan yang memang menyeluruh sehingga mereka dapat mewujudkan tujuan yang mereka inginkan. Bahkan sampai saat sekarang mereka masih berjuang untuk mendapatkan legalitas yang sah dari seluruh kalangan elemen masyarakat Lubuk Kilangan terkait KAN baru yang mereka miliki.

Ketiga, legitimasi kelompok dimata komunitas yang lebih luas atau setidaknya ada tekanan komunitas yang efektif terhadap kelompok. Upaya dalam mendapatkan legitimasi dimata kelompok yang lebih luas sampai saat sekarang masih mereka lakukan. Upaya pertama yang mereka lakukan adalah Musnalub Lubuk Kilangan untuk mendapatkan legitimasi dari masyarakat Lubuk Kilangan itu sendiri agar keberadaan kelompok mereka dapat diakui di tingkat masyarakat.

Setelah melakukan Musnalub KAN baru melanjutkan proses legitimasi mereka dengan secara administratif agar dapat berfungsi secara kelembagaan dalam menjalankan tugas- tugas mereka. Salah satu bentuk legitimasi yang dilakukan adalah meminta surat keputusan dari LKAAM kota padang untuk mengesahkan mereka secara utuh sebagai satu-satunya KAN yang ada di Lubuk Kilangan.

\section{Penyebab Terjadinya Konflik Kepengurusan KAN Lubuk Kilangan Periode 2017-2022}

Melalui kronologis yang peneliti terangkan diatas peneliti dapat menarik kesimpulan dari 4 tuntutan terjadinya konflik yang di utarakan oleh Junaidi Usman Dt Rajo Brahim di antaranya:

1. Kepengurusan baru mengambil keputusan atau tindakan tanpa adanya musyawarah untuk mufakat dengan niniak mamak yang tergabung di KAN

2. Memaksakan kepengurusan tetap berjalan sesuai kehendak sendiri atau kelompok

3. Melakukan penggalangan massa atas nama anak nagari untuk kepentingan sendiri 
atau kelompok

4. Melakukan atau membuat keputusan perjanjian dengan pihak lain yang menyangkut tanah ulayat nagari, tanpa melibatkan pihak-pihak yang harus dan mesti dilibatkan sesuai dengan PERDA Provinsi Sumatera Barat no. 09 Tahun 2000 tentang pemerintahan nagari dan PERDA Provinsi Sumatera Barat no 16 tahun 2008 tentang tanah ulayat.

Keempat tuntutan inilah yang menjadi penyebab dari konflik yang sampai saat sekarang masih bergulir tersebut. Peneliti lebih menyimpulkan konflik ini secara tersirat melalui penjelasan kedua belah pihak hadir karena otoritas yang kuat yang dimiliki oleh kepngurusan Basri Dt Rajo Usali yang sudah memasuki periode ke 3 dalam memimpin KAN Lubuk Kilangan.

Hal ini juga muncul dari beberapa keputusan yang dilakukan oleh pihak KAN lama dalam menanggapi persoalan tanah ulayat. Seperti yang dibunyikan dalam tuntutan ke 4 yaitu KAN lama tidak melibatkan semua pihak dalam memutuskan persoalan tanah ulayat yang melibatkan seluruh niniak mamak yang bersangkutan dan hal ini sudah diatur dalam Peraturan Daerah Provinsi Sumatera Barat No 16 Tahun 2008 tentang tanah ulayat. Walaupun secara terangterangan ketidakpuasan ini disampaikan melalui tuntutan tersebut namun tidak ada tanggapan dari pihak KAN lama membuat pernyataan yang diutarakan oleh ketua KAN lama seolah olah hanya dalih dari kekuasaan absolut yang sedang mereka jalankan. Peneliti melihat bahwa tidak adanya sinergi dari pernyataan tersebut dengan sikap yang dilakukan oleh pihak KAN lama sehingga membangun kelompok yang bertentangan sesuai dengan teori Ralf Dahrendorf. Kelompok bertentangan menurut Dahrendorf lahir dari hubungan-hubungan kekuasaan menjadi penghasil bentrokan-bentrokan kepentingan yang mana berdasarkan kondisi tertentu menyebabkan terbentuknya kelompok-kelompok yang bertentangan baik dalam organisasi sosial yang terbatas maupun dalam masyarakat keseluruhan ${ }^{26}$.

Kelompok bertentangan dalam pandangan Dahrendorf hadir atas ada beberapa interaksi antar individu senasib dan memiliki kepentingan yang sama. Dahrendorf juga menambahkan bahwa analisisnya dalam terbentuknya kelompok bertentangan lebih pada perseteruan wewenang dan kekuasaan. Kelompok bertentangan dapat hadir karena perbedaan pembagian kekuasaan dan wewenang yang senantiasa menjadi faktor yang menentukan pertentangan sosial sistematis yang berhubungan erat dengan pertentangan kelas menurut pengertian tradisional (Marxian) dari istilah ini $^{27}$.

\section{Pembagian Wewenang dan Kekuasaan KAN Lubuk Kilangan}

Pada Kecamatan Lubuk Kilangan terdapat 6 suku dibawah KAN Lubuk Kilangan maka ada 24 orang niniak mamak yang ada pada kepengurusan KAN Lubuk Kilangan28. Maka ada 6 orang penghulu yang memiliki peluang yang sama untuk menjadi Ketua KAN Lubuk Kilangan. pemilihan ketua KAN Lubuk Kilangan dilakukan dengan musyawarah yang diikuti oleh seluruh

\footnotetext{
${ }^{26}$ Ralf dahrendorf, Konflik dan Konflik Dalam Masyarakat Industri, CV Rajawali, Jakarta, 1986, hlm,201

${ }^{27}$ Ibid., hlm.201.

${ }^{28}$ Wawancara Bersama Basri Dt Rajo Usali Sebagai Ketua KAN Lubuk Kilangan Tempat di Warung Kopi
} 
niniak mamak Lubuk Kilangan yang tergabung dalam KAN.

Kekuasaan yang sama dari masing-masing penghulu tersebut yang menjadi asal mula dari konflik kepengurusan KAN Lubuk Kilangan. Setiap penghulu dari masing-masing suku yang memiliki peluang yang sama untuk menjadi ketua KAN merupakan bentuk dari perebutan wewenang. Perbedaan penting dari kekuasaan dan wewenang sebenarnya terletak pada kenyataan bahwa kekuasaan pada dasarnya berhubungan dengan kepribadian individu, sedangkan wewenang selalu berhubungan dengan peranan posisi atau peranan sosial ${ }^{29}$. Para penghulu telah memiliki kekuasaan secara tradisional dari sukunya namun belum mendapatkan wewenang untuk memerintah atau mendapatkan posisi yang diberi legitimasi oleh sebuah kelompok KAN.

KAN Lubuk Kilangan dibawah kepemimpinan Basri Dt Rajo Usali yang sudah memasuki periode ke-3 menimbulkan dominasi yang kuat di Lubuk Kilangan. Peran dominan yang beliau miliki menjadi dalah satu penyebab konflik di Lubuk Kilangan. Kesalahpahaman persoalan wewenang yang terjadi dalam kepengurusan ini peneliti menemukan adanya aspek historis yang muncul dari suku caniago dalam persoalan tanah ulayat ${ }^{30}$. Pada kasus itu niniak mamak caniago merasa dikerdilkan perannya dalam menyelesaikan persoalan tanah ulayat anak kamanakan sendiri (Kontan). Dominasi yang dimiliki oleh ketua KAN pada saat itu terlalu menyeluruh dan seringkali tidak melibatkan perwakilan dari niniak mamak dari suku masing-masing ${ }^{31}$. Persoalan ini sering sekali menjadi pemicu pertentangan kelompok ketika individu yang memegang peranan dominasi dalam suatu perserikatan tertentu tidak harus menyebabkan dominasi pula dalam semua perserikatan lainnya ${ }^{32}$.

\section{Terbentuknya Kelompok yang Bertentangan Dalam Konflik Kepengurusan KAN Lubuk Kilangan}

Setelah dikeluarkannya nama-nama kepengurusan untuk satu periode kedepan ada oknum niniak mamak yang merasa tidak setuju dengan kepengurusan yang telah dipilih oleh Basri Dt Rajo uasali. Nawirman Dt Manggung ialah oknum niniak mamak yang peneliti bunyikan pada pembahasan sebelumnya. Beliau adalah penghulu dari suku caniago posisi beliau sebagai penghulu dari sukunya membuat beliau dicalonkan sebagai ketua KAn Lubuk Kilangan. Namun, pada proses pemilihan beliau belum bisa menandingi ketua KAN lama yang menang untuk ke-3 kalinya. Setelah kalah pada pemilihan beliau juga tidak menemukan namanya pada kepengurusan baru sehingga beliau tidak kesepahaman dengan kepengurusan baru ini. Dapat dilihat adanya dua arah yang bertentangan dari kepentingan tersembunyi sebagai ciri khas struktur peranan serikat yang dikoordinasi secara memaksa ${ }^{33}$. Sehingga dalam organisasi

\footnotetext{
${ }^{29}$ Ralf dahrendorf, Konflik dan Konflik Dalam Masyarakat Industri, CV Rajawali, Jakarta, 1986, hlm,202

${ }^{30}$ Wawancara Bersama Junaidi Usman Dt Rajo Brahim Sebagai Ketua KAN baru Lubuk Kilangan, Tempat diKantor KAN baru Lubuk Kilangan yang Sekaligus Kediamannya.

${ }^{31}$ Wawancara Bersama Junaidi Usman Dt Rajo Brahim Sebagai Ketua KAN baru Lubuk Kilangan, Tempat diKantor KAN baru Lubuk Kilangan yang Sekaligus Kediamannya.

${ }^{32}$ Ralf dahrendorf, Konflik dan Konflik Dalam Masyarakat Industri, CV Rajawali, Jakarta, 1986, hlm,209.

33 ibid., hlm.220.
} 
tersebut hanya ada sekelompok orang yang memiliki sifat bersama karena wewenang yang mereka miliki bersama namun ada kepentingan yang berbeda dalam setiap tujuannya.

Setelah dilakukan tanya pendapat ini, Nawirman sangat ingin sekali mengadakan Munaslub untuk mengubah struktur dari KAN Lubuk Kilangan. Maka di kumpulkanlah kelompok niniak mamak yang berjumlah 13 orang tersebut untuk membentuk panitia Munaslub, selain niniak mamak juga ada beberapa anak nagari Lubuk Kilangan ${ }^{34}$. Panitia terpilih dari Munaslub ini adalah Candani Sebagai ketua dan Arsonetri sebagai sekretaris dalam Musnalub, Musnalub dilaksanakan pada tanggal 24 Maret 2018 di halaman Kantor KAN Lubuk Kilangan ${ }^{35}$. Musnalub Lubuk Kilangan dihadiri oleh 180 peserta yang diantaranya adalah 13 orang niniak mamak dan selebihnya diisi oleh anak nagari dan tokoh nagari Lubuk Kilangan.

Pada Musnalub tersebut menghasilkan beberapa kesepakatan yang hadir ditengah-tengah peserta Musnalub Lubuk Kilangan. Diantaranya Hasil dari kesepakatan Musnalub Lubuk Kilangan:

1. Membubarkan kepengurusan Kerapatan Adat Nagari (KAN) dibawah kepemimpinan Basri Dt Rajo Usali yang dianggap tidak legal atau tidak sah karena :

2. Sistem pemilihan tidak dilakukan secara demokratis dan transparan

3. Tidak pernah melaporkan pertanggungjawaban keuangan kepada anggota selama memimpin sudah dua kali periode

4. Melanggar aturan AD/ART bab VII pasal 14 tentang masa kepengurusan yang sudah berjalan dua kali periode

5. Mengabaikan permintaan niniak mamak pemangku adat anam suku Lubuk Kilangan untuk melaksanakan Musyawarah sesuai surat tuntutan pada tanggal 05 februari 2018 Selalu mengambil keputusan atau tindakan tanpa dimusyawarahkan dengan niniak mamak yang tergabung dalam Kerapatan

6. Membentuk segera struktur kepengurusan Kerapatan Adat nagari (KAN) yang demokratis dan transparan yang mekanisme pembentukannya diserahkan kepada niniak mamak penghulu anam suku Lubuk Kilangan.

7. Mengaktifkan kembali Badan Pengelolaan Aset dan Pembangunan Nagari (BPAPN) Lubuk Kilangan dengan menyempurnakan serta melengkapi kembali struktur kepengurusan.

8. Meminta laporan pertanggungjawaban keuangan kepada kepengurusan KAN Lubuk Kilangan dua periode sebelumnya (2007-20012 dan 20012-20017) dibawah kepemimpinan Basri Dt rajo Usali.

9. Menyepakati membentuk Majelis Pertimbangan Adat (MPA) Lubuk Kilangan

Hasil dari munaslub tersebut ditindaklanjuti dengan menetapkan dan menyetujui hasil pembentukan kepengurusan Kerapatan Adat Nagari (KAN) yang baru dibentuk secara demokratis dan transparan dengan struktur :

Pembina

: Musyawarah Pimpinan Kecamatan Muspika Kecamatan Lubuk

Kilangan

Penasehat : Syabirin Dt Rajo Sampono (Rang Tuo suku Caniago) Ismael Rajo

\footnotetext{
${ }^{34}$ Wawancara Bersama Junaidi Usman Dt Rajo Brahim Sebagai Ketua KAN baru Lubuk Kilangan, Tempat diKantor KAN baru Lubuk Kilangan yang Sekaligus Kediamannya

${ }^{35}$ Berita Acara Musyawarah Nagari Luar Biasa (Musnalub) Lubuk Kilangan
} 


$\begin{array}{ll}\text { Nan sati (Dubalang Suku Jambak) } \\ \text { Ketua } & \text { : Junaidi Usman Dt Rajo Brahim (Penghulu Suku Caniago) } \\ \text { Wk. Ketua } & \text { Nawirman Dt Tumangguang (Rangtuo Suku Koto) } \\ \text { Sekretaris } & \text { Zulbahri Malin Prakoso (Malin Malayu) } \\ \text { Wk. Sekretaris } & \text { : Nusran Rajo Nan Putih (Palo Mudo Suku Koto) } \\ \text { Bendahara } & : \text { H. Tasar Rajo Bagaga (Dubalang Suku Malayu) }\end{array}$

Semenjak ditandatangani berita acara ini, maka kepengurusan Kerapatan Adat Nagari dibawah kepemimpinan Basri Dt Rajo Usali Tidak Berfungsi Lagi ${ }^{36}$.

Setelah Musnalub Lubuk Kilangan barulah muncul KAN Lubuk Kilangan yang baru. Kemunculan KAN Baru tidak semerta merta begitu saja KAN Baru juga mendapatkan legalitas dari pihak Lembaga Kerapatan Adat Alam Minangkabau (LKAAM) Kota Padang. LKAAM menerbitkan Surat Keputusan 23 April 2018 No. 045/LKAAM-Padang/IV-2018. Kepengurusan KAN di bawah Kepemimpinan Junaidi Usman Dt Rajo Brahim berdasarkan hasil dari Musnalub Lubuk Kilangan pada 3 Mei 2018 resmi dikukuhkan oleh LKAAM Kota Padang.

Peneliti menemukan bahwa adanya kelompok yang bertentangan dalam konflik kepengurusan KAN Lubuk Kilangan. Hal ini dapat peneliti runut dari keinginan kuat yang dilakukan oleh Nawirman Dt Mangguang yang mau bekerja seorang diri untuk bisa menjatuhkan kekuasaan dari kepengurusan Basri Dt Rajo Usali. Kepentingan pada bagian ini peneliti menggunakan pemahaman Dahrendorf untuk menyamakan persepsi sebelum melanjutkan analis pembahasan ini. Kepentingan berarti pamrih atau arah perilaku yang lebih berkaitan dengan individu-individu dibandingkan dengan posisi mereka sendiri ${ }^{37}$. Kepentingan yang dimunculkan oleh Nawriman pada kepengurusan KAN Lubuk Kilangan adalah ingin menjadi bendahara dari kepengurusan baru Basri Dt Rajo Usali38. Sebagai seorang ketua beliau tentunya memilih kepengurusan yang memang sesuai dengan kebutuhan beliau dan kapasitas dari niniak mamak tersebut sehingga membuat beliau menyampingkan nama Nawirman pada pengurusannya $^{39}$. Pada kasus konflik kepengurusan ini adanya dua arah pertentangan dari kepentingan tersembunyi sebagai ciri khas struktur peranan perserikatan yang dikoordinasi secara memaksa, implikasinya tentu saja ini berarti bahwa posisi wewenang yang diperlengkapi dengan kepentingan yang diharapkan maupun orang yang memegang posisi wewenang itu mempunyai suatu sifat yang sama ${ }^{40}$. Sehingga pada suatu organisasi sosial akan mudah sekali terbentuknya kelompok yang bertentangan hal ini didasari dengan kepentingan tersembunyi dari anggota kelompok namun harus tunduk karena tugas dan wewenang.

Kepentingan tersembunyi merupakan salah satu unsur penyebab kelompok yang bertentangan. Kepentingan tersembunyi tersebut akan meredusir terbentuknya kelompok kepentingan dengan cara melakukan mobilisasi massa yang memiliki kepentingan yang sama dalam suatu kelompok kepentingan. Saat terbentuknya kelompok yang bertentangan maka

\footnotetext{
${ }^{36}$ Berita Acara Musyawarah Nagari Luar Biasa (Musnalub) Lubuk Kilangan

${ }^{37}$ Ralf dahrendorf, Konflik dan Konflik Dalam Masyarakat Industri, CV Rajawali, Jakarta, 1986, hlm 213.

${ }^{38}$ Wawancara Bersama Basri Dt Rajo Usali Sebagai Ketua KAN Lubuk Kilangan Tempat di Warung Kopi

${ }^{39}$ Wawancara Bersama Basri Dt Rajo Usali Sebagai Ketua KAN Lubuk Kilangan Tempat di Warung Kopi

${ }^{40}$ Dahrendorf,, op.cit., hlm 220.
} 
kepentingan tersembunyi akan berubah jadi kepentingan nyata yang disosialisasikan pada kelompok tersebut. Kelompok kepentingan adalah agen yang sesungguhnya dari terciptanya kelompok yang bertentangan ${ }^{41}$. Pada kasus Lubuk Kilangan kita melihat Nawirman sebagai salah satu niniak mamak yang memiliki kepentingan tersembunyi lalu membentuk kelompok pentingan ini dengan mengajak Zulbahri dan Junaidi Usman sebagai anggota mereka dengan mengedepankan keresahan yang sama.

\section{Kesimpulan}

Konflik kepengurusan Kerapatan Adat Nagari (KAN) Lubuk Kilangan sudah bisa disebut bukan lagi sebagai rahasia umum. Lubuk Kilangan yang identik dengan PT Semen Padang dalam persoalan hak pakai tanah ulayat (bukit karang putih) Lubuk Kilangan. KAN merupakan lembaga adat tradisional yang masih aktif sampai saat sekarang, fungsi KAN yang sangat dibutuhkan oleh masyarakat Lubuk Kilangan. Hal ini tidak bisa dikesampingkan karena banyaknya fungsi dan tugas dari KAN yang sangat dibutuhkan pada msayarakat Lubuk Kilangan.

Konflik kepengurusan yang terjadi pada kepengurusan KAN Lubuk Kilangan merupakan konflik laten yang sudah berlangsung selama 2 tahun semenjak terpilihnya kepengurusan baru KAN Lubuk Kilangan. Konflik ini masih termasuk konflik lisan karena belum ada benturan yang berbau fisik dalam konflik ini. Konflik ini menurut dahrendorf merupakan konflik kelompok- kelompok terorganisir yang bermula dari kelompok yang bertentangan. Sehingga kemunculan KAN baru di Lubuk Kilangan menjadi legal dengan menggunakan Surat keputusan dari LKAAM Kota Padang. Tidak bisa dipungkiri konflik ini merupakan bentuk perebutan wewenang yang ada dalam kepengurusan KAN Lubuk Kilangan.

Penyebab Konflik kepengurusan ini tidak bisa dihindarkan dari kepentingan niniak mamak yang membuat sebuah kelompok semu untuk melemahkan kepengurusan lama. Melalui tuntutan yang dilakukan oleh kelompok semu tersebut akhirnya menjadi kelompok yang terorganisir yang akhirnya bisa menandingi keberadaan kepengurusan KAN periode 2017-2022. Konflik ini juga diisi dengan pertentangan dikotomi wewenang yang memnurut sebagian niniak mamak Lubuk Kilangan dominasi pengurus inti membuat wewenang niniak mamak masing-masing suku akhirnya tidak mendapatkan porsi wewenang yang sama pada KAN Lubuk Kilangan.

Sehingga peran niniak mamak Lubuk Kilangan dalam membimbing anak kamanakan menjadi hilang. Niniak mamak yang seharusnya hadir secara adat malah berubah fungsi untuk merebutkan sumber-sumber yang menurut peneliti tidak banyak menguntungkan anak kamanakan sendiri. Sehingga niniak mamak lebih sibuk dengan kepentingan pribadi dari pada kepentingan suku masing-masing. Peneliti juga mencurigai selain adanya dana legal yang masuk dalam khas KAN Lubuk Kilangan dan juga dana illegal yang langsung masuk kekantong pribadi niniak mamak.

\section{DAFTAR PUSTAKA}

\section{Buku}

${ }^{41}$ Ralf dahrendorf, Konflik dan Konflik Dalam Masyarakat Industri, CV Rajawali, Jakarta, 1986, hlm 222. 
Afrizal. 2014."Metode Penelitian Kualitatif'. Jakarta: Rajawali Pers

Bungin, Burhan. 2007. "Penelitian Kualitatif" Jakarta: Kencana Prenada Media Group Bottomore T.B. 2006. "Elit dan Masyarakat", Jakarta : Akbar Tndjung Institute

Dahrendorf Ralf. 1986. "Konflik dan Konflik dalam Masyarakat Industri”, Jakarta : CV Rajawali Keller Suzanne, 1995. "Penguasa dan Kelompok Elit "peranan elit-penentu dalam masyarakat Modern", Jakarta : PT Grafindo Persada

Giddens, Anthoni,2007 “Kapitalisme dan Teori Sosial Modern” Jakarta, Universitas Indonesia (UI- PPRESS)

M.S. Amir. 2003. “Adat Minangkabau Pola dan Tujuan Hidup Orang Minang”, Jakarta: PT Mutiara Sumber Widya

Nuraini Budi Astuti, Lala M. Kolopaking dkk (2009), “ Dilema dalam transformasi Desa ke nagari: Studi kasus di Kenagarian IV Koto Palembayan, Provinsi Sumatera Barat”, (Jurnal Transdisiplin Sosiologi, Komuniskasi dan Ekologi Manusia), Volume 3(2), hlm. 153-172.

PruItt, Dean G dan Rubin. Jefreyy Z. 2011. “Teori Konflik Sosial”, Yogyakarta: Pustaka Pelajar Rauf Maswadi. 2000. "Konsensus Politik”, Jakarta : Direktorat Jendral Pendidikan Tinggi, Departemen Pendidikan Nasional

Riski Fazila, Maimun (2017), "Dualisme Kepengurusan Pusat Partai Persatuan Pembangunan Menjelang Pilkada Serentak 2017 (Satuan Kajian Terhadap Dewan Pimpinan Partai Persatuan Pembangunan Aceh)", Jurnal Ilmiah FISIP Unsyiah Volume 2,(2) : Hlm 481501.

Surbakti Ramlan. 2010. “Memahami Ilmu Politik”, Jakarta : PT Grasindo

Yayah Hidayat, Iwan I. febrianto dkk, (2017) " Transformasi dan Dualisme Kelembagaan dalam Pemerintahan Adat Minang: Studi Terhadap Nagari Pariangan sumatera Barat”, Politik Indonesia Political Science Review, Volume 2,(2) : 227-245.

Yin, Robert K. 2003, "Studi Kasus Desain dan Metode", Jakarta: PT Raja Grafindo Persada 